

\title{
Methods and Reviews
}

\section{Volume 1}

Edited by

Elliot Elson

William Frazier

and

Luis Glaser

Washington University School of Medicine

St. Louis, Missouri 


\section{CONTENTS}

Chapter 1

Sugar-Cation Cotransport Systems in Bacteria

T. Hastings Wilson and Dorothy M. Wilson

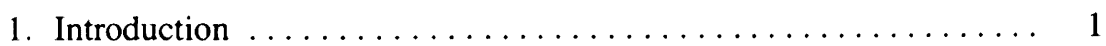

2. Lactose Transport in Escherichia coli ................ 2

2.1. Early Studies ........................ 2

2.2. Methods for Study of Transport $\ldots \ldots \ldots \ldots \ldots \ldots \ldots .2$

2.3. Substrates for Transport $\ldots \ldots \ldots \ldots \ldots \ldots \ldots \ldots \ldots \ldots$

2.4. Lactose- $\mathrm{H}^{+}$Cotransport ................. 4

2.5. Chemical Identification of the Lactose Carrier ........ 5

2.6. Amplification of the Lactose Carrier Protein $\ldots \ldots \ldots \ldots 7$

2.7. DNA Sequence ........................ 7

2.8. Is there Processing of the Lactose Carrier? ......... 9

2.9. The SH Groups of the Carrier Protein $\ldots \ldots \ldots \ldots \ldots \ldots 10$

2.10. Solubilization and Reconstitution of the Lactose Carrier .... 10

2.11. Purification of the Carrier in an Active Form .......... 13

2.12. Kinetics ............................ 14

2.13. Effect of $\Delta \bar{\mu}_{\mathrm{H}^{+}}$on the Structure of the Carrier $\ldots \ldots \ldots \ldots 17$

2.14. Mutants of the Lactose Carrier $\ldots \ldots \ldots \ldots \ldots \ldots \ldots, 18$

2.15. Other Mutants Affecting Lactose Transport .......... 20

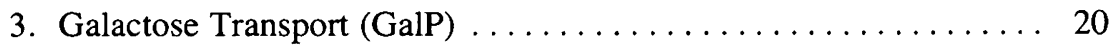

3.1. E. coli ........................... 20





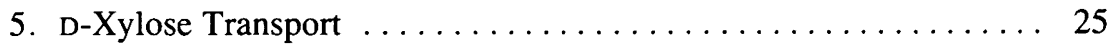




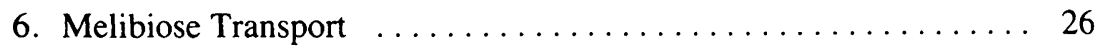

6.1. Substrate and Inducer Specificities ............. 27

6.2. Cation Requirements ..................... 27

6.3. Reconstitution of the Melibiose Carrier . .......... 29

6.4. Mutants .......................... 30

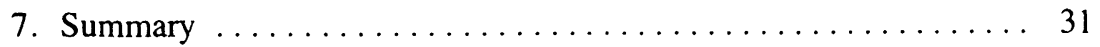

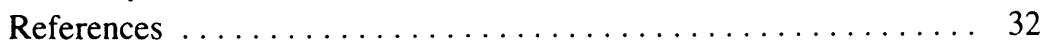

\section{Chapter 2}

The Structure and Function of Band 3

Ian G. Macara and Lewis C. Cantley

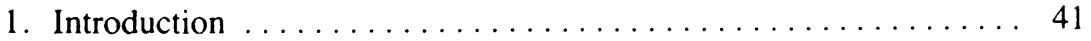

2. Purification and Reconstitution $\ldots \ldots \ldots \ldots \ldots \ldots \ldots \ldots \ldots, 42$

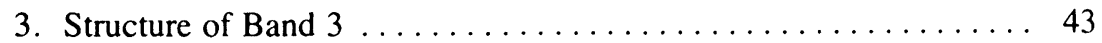

3.1. The Cytoplasmic Domain $\ldots \ldots \ldots \ldots \ldots \ldots \ldots \ldots . \ldots 44$

3.2. The Membrane-Bound Domain $\ldots \ldots \ldots \ldots \ldots \ldots \ldots . \ldots 45$

3.3. Transport Site Structure $\ldots \ldots \ldots \ldots \ldots \ldots \ldots \ldots \ldots . \ldots \ldots$

3.4. Quaternary Structure of Band $3 \ldots \ldots \ldots \ldots \ldots \ldots \ldots$

3.5. Posttranslational Modifications of Band $3 \ldots \ldots \ldots \ldots 57$

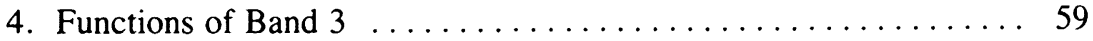

4.1. Functions of the Cytoplasmic Domain ............ 59

4.2. Functions of the Membrane-Bound Domain .......... 65

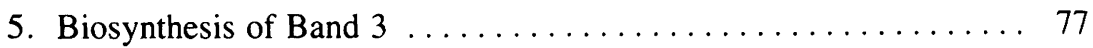

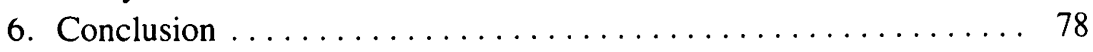

References ............................. 79

\section{Chapter 3}

Biosynthesis and Assembly of Mitochondrial Proteins

Martin Teintze and Walter Neupert

1. Introduction $\ldots \ldots \ldots \ldots \ldots \ldots \ldots \ldots \ldots \ldots \ldots \ldots \ldots \ldots$

2. Post- vs. Cotranslational Transport $\ldots \ldots \ldots \ldots \ldots \ldots \ldots \ldots . \ldots \ldots$

3. Precursor Forms of Mitochondrial Proteins $\ldots \ldots \ldots \ldots \ldots \ldots . . \ldots 2$

4. Evidence for the Existence of Specific Receptors . . . . . . . . . 97

5. Transfer of Many Proteins Requires a Membrane Potential ...... 99

6. Proteolytic Processing Enzymes . . ................. 102

7. Different Organisms Have Closely Related Transfer Machineries .. 103 
8. Functional Assembly of Mitochondrial Enzyme Complexes .... 105

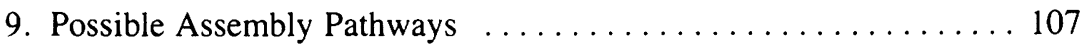

References .............................111

Chapter 4

Polypeptide-Hormone-Induced Receptor Clustering and Internalization

J. Schlessinger, A. B. Schreiber, T. A. Libermann, I. Lax, A. Avivi, and $Y$. Yarden

1. Introduction .................................... 117

2. Receptor-Mediated Endocytosis of Polypeptide Hormones, Growth Factors, and Other Serum Proteins $\ldots \ldots \ldots \ldots \ldots \ldots \ldots \ldots$

3. The Clustering and Internalization of EGF Receptors . . . . . . 129

3.1. The Dynamic Properties of EGF Receptors on Human Tumor Cells (A-431) ...................... 131

3.2. Monoclonal Antibodies against the EGF Receptor: A Powerful Tool for the Purification of the EGF Receptor and for the Investigation of Its Mode of Action . . . . . . . 135

References

Chapter 5

The Voltage-Sensitive Sodium Channel

William A. Catterall

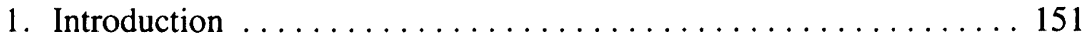

2. Neurotoxins as Probes of Sodium Channel Structure and Function 153

2.1. Inhibitory Toxins Acting at Neurotoxin Receptor Site 1 . . 154

2.2. Lipid-Soluble Toxins Acting at Neurotoxin Receptor Site 2156

2.3. Polypeptide Toxins Acting at Neurotoxin Receptor Site 3 .. 159

3. Molecular Properties of Sodium Channels Inferred from Functional Studies ...................................... 162

3.1. Ion Transport and the Ion Selectivity Filter $\ldots \ldots \ldots \ldots 162$

3.2. An Essential Carboxyl Group at the Tetrodotoxin/Saxitoxin Receptor Site ....................... 166

3.3. Evidence for a Voltage-Dependent Conformational Change Associated with Sodium Channel Activation .......... 167

3.4. Protein Components Involved in Sodium Channel Inactivation 
3.5. Allosteric Interactions among Functionally Distinct Sodium Channel Components ....................... 173

4. Identification and Purification of Protein Components of Sodium Channels ................................. 175

4.1. Identification of Protein Components of the Sodium Channel

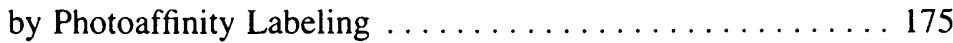

4.2. Solubilization and Size Characteristics of the Saxitoxin/ Tetrodotoxin Receptor of the Sodium Channel ......... 177

4.3. Purification of the Solubilized Saxitoxin Receptor of the Sodium Channel ....................... 178

4.4. The Sodium Channel as a Glycoprotein ........... 182

4.5. Progress toward Reconstitution of Sodium Channel Function from Purified Components ..................... 183

References ............................. 187

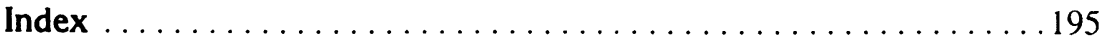




\title{
3
}

\section{BIOSYNTHESIS AND ASSEMBLY OF MITOCHONDRIAL PROTEINS}

\author{
Martin Teintze and Walter Neupert
}

\section{INTRODUCTION}

Eukaryotic cells are divided into a number of subcellular compartments, each surrounded by one or more membranes. By creating these compartments (i.e., organelles), eukaryotic cells have evolved a host of new capabilities compared to the simpler prokaryotic cells. The creation within the cell of compartments enclosed by membranes allows, for instance, the use of metabolic pathways in opposite directions at the same time, or the storage of substances (such as $\mathrm{Ca}^{2+}$ in the sarcoplasmic reticulum) where they can be released when needed to initiate reactions. Proteolytic enzymes can be sequestered where they do not interfere with other cell functions, and ion or proton gradients can be generated across membranes within the cell to drive reactions such as the synthesis of ATP. This increased complexity, however, brings with it a host of new problems for the eukaryotic cell. A major one is that almost all the proteins of the intracellular organelles are synthesized on cytoplasmic ribosomes (Schatz and Mason, 1974; Chua and Schmidt, 1979). Hundreds of different proteins must be directed into their proper organelles during or after translation. The membranes of these organelles, on the other hand, are practically impermeable to macromolecules such as proteins. Therefore mechanisms must exist for specifically transferring newly synthesized proteins into or across the membrane or membranes of the proper organelle.

Most theories that attempt to explain this phenomenon postulate the

Martin Teintze and Walter Neupert - Institute of Biochemistry, University of Göttingen, D-3400 Göttingen, Federal Republic of Germany. 
existence of complementary structures on the proteins and the organelles, i.e., receptors in the outer membranes of these organelles. Receptor proteins would be able to bind specifically a protein or class of proteins destined for an organelle during or after its synthesis and mediate its transport into or across the membrane.

Although no such receptor proteins have been isolated yet, the evidence suggesting their existence has been growing (Hennig and Neupert, 1981). The transfer of proteins from their site of synthesis to their functional site is irreversible; this requires that the proteins be synthesized as precursors that are in some way different from the mature functional form of the protein. Some of the ways by which this is accomplished will be discussed in the following sections.

Two kinds of organelles, the mitochondria and the chloroplasts, have their own DNA and ribosomes and are able to synthesize a few of their own proteins. A number of those are subunits of enzyme complexes that also contain subunits coded for on nuclear genes and synthesized on cytoplasmic ribosomes. Very little is known to date about how these two synthetic systems are coordinated so that these enzyme complexes are assembled with stoichiometric ratios of subunits.

The study of the molecular mechanisms of intracellular protein transport involves following single, well-defined proteins that can be assigned to one particular organelle over the entire path from the synthetic origin to the functional site. This requires isolation and purification of such proteins and the preparation of specific antibodies with which one can detect the minute quantities of precursors or intermediates that might be involved in the transfer process.

Many studies on intracellular protein transport have focused on mitochondria. A large number of mitochondrial proteins have been well-characterized with respect to structure, localization, and site of synthesis. Mitochondria can easily be separated from the remaining cell components, allowing separation of the synthesis and transfer processes.

\section{POST- VS. COTRANSLATIONAL TRANSPORT}

There are probably several different mechanisms by which proteins synthesized in the eukaryotic cell reach their final destinations. The proteins 
whose intracellular transport has been studied can be divided into two major classes: those that are transported cotranslationally and those that are transported posttranslationally.

Cotranslational transport is observed in the endoplasmic reticulum (ER) and probably the plasma membrane of bacteria (Sabatini et al., 1982). Proteins that are destined to be secreted via the Golgi apparatus or have their functional site in the lumen of the endoplasmic reticulum are synthesized by ribosomes bound to the cytoplasmic face of the ER membrane (Palade, 1975; Blobel and Dobberstein, 1975). The nascent polypeptide chain is discharged through the membrane during protein synthesis, before the polypeptide is fully folded.

Some details of the cotranslational mechanism have recently been elucidated. An $11 \mathrm{~S}$ protein composed of six polypeptides was purified from dog pancreas rough microsomes and was shown to bind to polysomes synthesizing secretory proteins. Since it apparently recognizes the amino terminal signal sequence of the nascent polypeptide, it was termed the "signal recognition protein" (SRP) (Walter et al., 1981). This protein complex apparently also mediates the binding of the polysomes synthesizing the secretory protein to microsomal membranes (Walter and Blobel, 1981a) and stops chain elongation until the SRP-ribosome complex binds to the microsomal membrane (Walter and Blobel, 1981b). The receptor for the SRP or "docking protein" has been identified as an integral glycoprotein $\left(M_{r} 72,000\right)$ of the ER membrane (Walter et al., 1979; Meyer and Dobberstein, 1980; Meyer et al., 1982). Furthermore, the rough ER contains ribosome binding sites called ribophorins (Kreibich $e t$ al., 1978) that may serve to keep the ribosome attached to the membrane while elongation of the polypeptide is completed. During this second elongation phase the polypeptide traverses the membrane and a "signal peptidase" removes the signal sequence from the nascent chain (Jackson and Blobel, 1977). A "leader peptidase" has also been isolated from $E$. coli inner and outer membranes (Zwizinski and Wickner, 1980).

On the other hand, the intracellular transport of a large number of proteins into mitochondria, as well as chloroplasts, glyoxysomes, and peroxisomes, has been shown to take place by a posttranslational mechanism (Chua and Schmidt, 1979; Neupert and Schatz, 1981). This means that synthesis of the precursor protein is separated in both space and time from the transfer into the organelle rather than being obligatorily coupled as in cotranslational transport.

Two different types of experiments have been employed to follow the biogenesis of a mitochondrial protein. In in vivo pulse-labeling studies one 
can often detect the precursors, if they differ in molecular weight or immunological properties from the mature proteins, and follow their processing by lysing the cells at different time points and immunoprecipitating the proteins. These experiments show that processing and transfer still occur when protein synthesis has been stopped with cycloheximide, and that labeled precursors appear in the cytosol before the labeled proteins appear in the mitochondrial fraction (Hallermayer et al., 1977; Schatz, 1979; Teintze et al., 1982). It is difficult to tell on what type of ribosome a protein is made, however, or where it is localized in the cell.

Experiments can also be done in vitro using precursors synthesized in a homologous or heterologous cell-free system and isolated mitochondria. These can be resuspended in the postribosomal supernatant of the cell-free system after protein synthesis has been completed, and import of precursor proteins into the mitochondria in the absence of protein synthesis can be observed (Korb and Neupert, 1978; Maccecchini et al., 1979a; Zimmermann and Neupert, 1980). In this type of experiment one can distinguish proteins that remain in solution, those that are bound to recognition sites on the mitochondria but still accessible to externally added proteases, and those that have been imported into a protease-resistant and/or functional location in the mitochondria. The results show that as the precursors disappear from the supernatant they are first bound to the outside of the mitochondria and then transferred to their functional site. It is during this second step that they are converted to their mature, functional form.

So far almost all mitochondrial precursor proteins studied are synthesized on free polysomes and are transferred posttranslationally (Table I). However, general rules for transfer into organelles cannot be drawn. In fact, insertion of proteins into ER or plasma membranes appears to obey both mechanisms, depending on the protein (Sabatini et al., 1982). Transfer of proteins into the plasma membrane of bacteria may also occur by both cotranslational and posttranslational pathways (Wickner, 1980).

\section{PRECURSOR FORMS OF MITOCHONDRIAL PROTEINS}

The mitochondrial proteins that are made on cytoplasmic ribosomes are synthesized as precursors that can be immunoprecipitated after pulse-labeling cells in vivo or after synthesis in an in vitro cell-free system. Many of these 
TABLE I. Mitochondrial Precursor Proteins

\begin{tabular}{|c|c|c|c|c|c|c|c|c|}
\hline Protein & $\begin{array}{l}\text { Organism } \\
\text { or tissue }\end{array}$ & $\begin{array}{l}\text { Location in } \\
\text { mitochondrion }\end{array}$ & $\begin{array}{l}\text { Site of synthesis } \\
\text { (polysomes) }\end{array}$ & $\begin{array}{l}\text { Posttranslational } \\
\text { transfer shown }\end{array}$ & $\begin{array}{l}\text { Energy- } \\
\text { dependent }\end{array}$ & $\begin{array}{c}\text { Precursor } \\
\text { MW (approx.) }\end{array}$ & $\begin{array}{c}\text { Mature } \\
\text { MW (approx.) }\end{array}$ & Reference(s) \\
\hline Porin & Neurospora & Outer membrane & Free & Yes & No & 31.000 & 31,000 & Freitag et al. $(1982 \mathrm{a}, \mathrm{b})$ \\
\hline Cytochrome $b_{2}$ & Yeast & $\begin{array}{l}\text { Intermembrane } \\
\text { space }\end{array}$ & N.D. ${ }^{a}$ & Yes & Yes & 68.000 & 58.000 & Gasser el al. (1982) \\
\hline $\begin{array}{r}\text { Cytochrome } c \\
\text { peroxidase }\end{array}$ & Yeast & $\begin{array}{l}\text { Intermembrane } \\
\text { space }\end{array}$ & N.D. & Yes & No & 39.500 & 33.500 & $\begin{array}{l}\text { Maccecchini et al. (1979b), } \\
\text { Nelson and Schatz (1979) }\end{array}$ \\
\hline $\begin{array}{l}\text { Sulfite } \\
\quad \text { oxidase }\end{array}$ & Rat liver & $\begin{array}{l}\text { Intermembrane } \\
\text { space }\end{array}$ & Free & No & N.D. & 59.000 & 55.000 & Mihara et al. (1982) \\
\hline \multirow[t]{2}{*}{ Cytochrome $c$} & Neurospora & $\begin{array}{l}\text { Intermembrane } \\
\text { space-inner membrane }\end{array}$ & Free & Yes & No & 12.000 & 12,000 & $\begin{array}{l}\text { Korb and Neupert (1978), } \\
\text { Zimmermann et al. } \\
\text { (1979a, 1981) }\end{array}$ \\
\hline & Rat liver & $\begin{array}{l}\text { Intermembrane } \\
\text { space-inner membrane }\end{array}$ & Free & Yes & No & 12.000 & 12,000 & Matsuura et al. (1981) \\
\hline ADP/ATP carrier & Neurospora & Inner membrane & Free & Yes & Yes & 32,000 & 32,000 & $\begin{array}{l}\text { Zimmermann et al. (1979b) } \\
\text { Zimmermann and Neuper } \\
(1980)\end{array}$ \\
\hline $\begin{array}{l}\text { ATPase } \\
\text { subunit } 9\end{array}$ & Neurospora & Inner membrane & Free & Yes & Yes & 12,000 & 8.000 & $\begin{array}{l}\text { Michel et al. (1979), } \\
\text { Zimmerman et al. (1981) }\end{array}$ \\
\hline $\begin{array}{l}\text { Cytochrome } b c_{1} \\
\text { complex }\end{array}$ & Neurospora & Inner membrane & N.D. & Yes & Yes & 51,500 & 50,000 & Teintze et al. (1982) \\
\hline \multicolumn{9}{|l|}{ Subunit I } \\
\hline Subunit II & & & N.D. & Yes & Yes & 47.500 & 45,000 & \\
\hline Cytochrome $c_{1}$ & & & Free & Yes & Yes & 38,000 & 31.000 & \\
\hline Subunit V & & & N.D. & Yes & Yes & 28.000 & 25,000 & \\
\hline Subunit VI & & & N.D. & No & N.D. & 14,000 & 14,000 & \\
\hline Subunit VII & & & N.D. & Yes & Yes & 12.000 & 11,500 & \\
\hline Subunit VIII & & & N.D. & No & N.D. & 11.600 & 11,200 & \\
\hline $\begin{array}{l}\text { Cytochrome } b c_{1} \\
\text { complex }\end{array}$ & Yeast & & & & & & & $\begin{array}{l}\text { Côté et al. (1979), } \\
\quad \text { Nelson and Schatz (1979) }\end{array}$ \\
\hline Cytochrome $c_{1}$ & & & N.D. & No & Yes & 37,000 & 31.000 & \\
\hline Subunit V & & & N.D. & No & Yes & 27,000 & 25,000 & \\
\hline
\end{tabular}

(Continued) 
TABLE I. (Continued)

\begin{tabular}{|c|c|c|c|c|c|c|c|c|}
\hline Protein & $\begin{array}{l}\text { Organism } \\
\text { or tissue }\end{array}$ & $\begin{array}{l}\text { Location in } \\
\text { mitochondrion }\end{array}$ & $\begin{array}{l}\text { Site of synthesis } \\
\text { (polysomes) }\end{array}$ & $\begin{array}{l}\text { Posttranslational } \\
\text { transfer shown }\end{array}$ & $\begin{array}{l}\text { Energy- } \\
\text { dependent }\end{array}$ & $\begin{array}{c}\text { Precursor } \\
\text { MW (approx.) }\end{array}$ & $\begin{array}{c}\text { Mature } \\
\text { MW (approx.) }\end{array}$ & Reference(s) \\
\hline $\begin{array}{c}\text { Cytochrome } c \\
\text { oxidase }\end{array}$ & Rat liver & Inner membrane & & & & & & $\begin{array}{l}\text { Schmelzer and Heinrich } \\
\text { (1980), Heinrich (1982) }\end{array}$ \\
\hline Subunit IV & & & Free + bound & No & N.D. & 19.500 & 16.500 & \\
\hline Subunit V & & & Free + bound & No & N.D. & 15.500 & 12.500 & \\
\hline Cytochrome $c$ oxidase & Yeast & Inner membrane & & & & & & $\begin{array}{l}\text { Lewin et al. (1980), } \\
\text { Mihara and Blobel, (1980) }\end{array}$ \\
\hline Subunit IV & & & N.D. & No & N.D. & - & - & \\
\hline Subunit V & & & N.D. & Yes & N.D. & - & - & \\
\hline Subunit VI & & & N.D. & No & N.D. & 20,000 & 12.500 & \\
\hline Subunit VII & & & N.D. & No & N.D. & & & \\
\hline $\begin{array}{l}\text { Cytochrome } \\
{\mathrm{P} 450_{\mathrm{scc}}}\end{array}$ & $\begin{array}{l}\text { Bovine adrenal } \\
\text { cortex }\end{array}$ & Inner membrane & N.D. & No & N.D. & 54.500 & 49.000 & DuBois et al. (1981) \\
\hline $\begin{array}{l}\text { Cytochrome } \\
\text { P450 } 11-\beta\end{array}$ & $\begin{array}{l}\text { Bovine adrenal } \\
\text { cortex }\end{array}$ & Inner membrane & Free + bound & No & N.D. & 50.000 & 45.000 & Nabi et al. (1980) \\
\hline$F_{1}$-ATPase & Yeast & $\begin{array}{l}\text { Matrix-inner } \\
\text { membrane }\end{array}$ & & & & & & $\begin{array}{l}\text { Maccecchini et al. (1979a), } \\
\text { Nelson and Schatz (1979), }\end{array}$ \\
\hline$\alpha$ Subunit & & & N.D. & Yes & Yes & 64.000 & 58,000 & Lewin et al. (1980) \\
\hline$\beta$ Subunit & & & N.D. & Yes & Yes & 56,000 & 54.000 & \\
\hline$\gamma$ Subunit & & & N.D. & Yes & Yes & 40.000 & 34.000 & \\
\hline Adrenodoxin & $\begin{array}{l}\text { Bovine adrenal } \\
\text { cortex }\end{array}$ & Matrix & Free + bound & Yes & N.D. & 20,000 & 12,000 & Nabi and Omura (1980) \\
\hline $\begin{array}{l}\text { ס-Aminolevu- } \\
\text { linic acid } \\
\text { synthetase }\end{array}$ & Rat liver & Matrix & Free & No & N.D. & 51.000 & 45.000 & Yamauchi et al. $(1980 \mathrm{a}, \mathrm{b})$ \\
\hline \multirow[t]{2}{*}{$\begin{array}{l}\text { Aspartate } \\
\quad \text { aminotrans- } \\
\quad \text { ferase }\end{array}$} & $\begin{array}{c}\text { Chicken } \\
\text { heart }\end{array}$ & Matrix & Free & No & N.D. & 47.500 & 44.500 & $\begin{array}{l}\text { Sonderegger et al. (1980. } \\
\text { 1982) }\end{array}$ \\
\hline & Rat liver & Matrix & Free & Yes & N.D. & 47,000 & 45,000 & Sakakibara et al. (1980) \\
\hline $\begin{array}{l}\text { Carbamoyl- } \\
\text { phosphate } \\
\text { synthetase }\end{array}$ & Rat liver & Matrix & Free & Yes & N.D. & 165.000 & 160,000 & $\begin{array}{l}\text { Mori et al. (1979), } \\
\text { Raymond and Shore } \\
\text { (1979, 1980), } \\
\text { Shore et al. (1979) }\end{array}$ \\
\hline
\end{tabular}




\begin{tabular}{|c|c|c|c|c|c|c|c|c|}
\hline $\begin{array}{l}\text { Citrate } \\
\quad \text { synthase }\end{array}$ & Neurospora & Matrix & N.D. & No & N.D. & 47.000 & 44,500 & Harmey and Neupert (1979) \\
\hline $\begin{array}{l}\text { L-Glutamate } \\
\text { dehydrogenase }\end{array}$ & Rat liver & Matrix & Free & No & N.D. & 60.000 & 54.000 & Mihara et al. (1982) \\
\hline $\begin{array}{l}D-\beta \text {-Hydroxy- } \\
\text { butyrate } \\
\text { dehydrogenase }\end{array}$ & Rat liver & Matrix & Free & No & N.D. & 37,000 & 32.000 & Mihara et al. (1982) \\
\hline $\begin{array}{l}\text { Malate } \\
\quad \text { dehydrogenase }\end{array}$ & Rat liver & Matrix & Free & No & N.D. & 38.000 & 37.000 & Mihara et al. (1982) \\
\hline $\begin{array}{l}\text { Ornithine } \\
\text { carbamoyl- } \\
\text { transferase }\end{array}$ & Rat liver & Matrix & N.D. & Yes & Yes & $\begin{array}{l}39,400 \\
43.000\end{array}$ & $\begin{array}{l}36,000 \\
39,000\end{array}$ & $\begin{array}{l}\text { Mori et al. (1980) } \\
\text { Conboy and Rosenberg (1981), } \\
\quad \text { Morita et al. (1982) }\end{array}$ \\
\hline $\begin{array}{l}\text { Superoxide } \\
\text { dismutase }\end{array}$ & Yeast & Matrix & N.D. & No & Yes & 26.000 & 24,000 & Autor (1982) \\
\hline
\end{tabular}

a N.D.. not determined 
precursors have an additional sequence that is removed by a proteolytic enzyme during or after the transfer process. Their apparent molecular weights are larger than those of the mature proteins by anywhere from 500 daltons for subunit VII of the Neurospora cytochrome $b c_{1}$ complex (Teintze et al., 1982) to 10,000 daltons for cytochrome $b_{2}$ (Gasser et al., 1982). Other proteins for which this type of transfer with proteolytic processing has been observed are listed in Table I.

For cytochrome $c_{1}$ in Neurospora (Teintze et al., 1982) and for cytochromes $c_{1}$ and $b_{2}$ in yeast (Gasser et al., 1982), the proteolytic processing takes place in two separate steps via a form with intermediate molecular weight.

Some mitochondrial proteins, however, are synthesized with the same molecular weight as the mature functional protein and are transferred without proteolytic processing. These include cytochrome $c$ (Zimmermann et al., 1979a), the ADP/ATP carrier (Zimmermann et al., 1979b), subunit VI of the cytochrome $b c_{1}$ complex (Teintze et al., 1982), and the outer membrane porin (Freitag et al., 1982b). In these cases there must be some kind of conformation change that allows the proteins to get into or through the membrane and prevents them from leaving their compartment.

The most extensively studied example of this type of transfer process is that of cytochrome $c$, because it is the only imported protein whose precursor, apocytochrome $c$, has been prepared in large quantities. Apocytochrome $c$ is transferred across the outer membrane into the intermembrane space in conjunction with the covalent attachment of a heme group to form mature holocytochrome $c$ (Hennig and Neupert, 1981). The heme group can be removed from isolated holocytochrome $c$ to produce chemical quantities of apocytochrome $c$, which is identical to the precursor synthesized in the cell. Antibodies prepared against Neurospora apo- and holocytochrome $c$ do not cross-react (Korb and Neupert, 1978). Excess unlabeled apocytochrome $c$, but not holocytochrome $c$, can compete with radioactive apocytochrome $c$ for binding and transfer into Neurospora mitochondria (Hennig and Neupert, 1981).

Thus, upon addition of the heme group, the protein probably undergoes a conformational change that results in transfer of the holocytochrome $c$ into the intermembrane space.

No covalent modifications have been detected so far for any of the other mitochondrial protein precursors that are imported without proteolytic processing. The precursor of the ADP/ATP carrier of Neurospora mitochondria synthesized in vitro in a heterologous cell-free system has the same apparent 
molecular weight on sodium dodecylsulfate gels as the mature protein and was shown not to have an additional sequence at the $\mathrm{N}$ terminal by translation in the presence of $N$-formyl[ $\left.{ }^{35} \mathrm{~S}\right]$ methionyl-tRNA (Zimmermann et al., 1979b). The precursors were found to be present as soluble aggregates with molecular weights in the range of 100,000 to 500,000 (Zimmermann and Neupert, 1980), whereas the mature protein is an insoluble integral inner membrane protein with a molecular weight of about 30,000 .

The outer membrane porin of Neurospora mitochondria, which is also synthesized with the same molecular weight as the mature protein (Freitag et al., 1982b), has recently been isolated in a water-soluble lipid-free form $(\mathrm{H}$. Freitag and W. Neupert, unpublished observations). This water-soluble form of porin can compete with the in-vitro-synthesized precursor for binding and transfer into mitochondria, unlike isolated porin, which contains lipid and can only be solubilized in the presence of detergent.

\section{EVIDENCE FOR THE EXISTENCE OF SPECIFIC RECEPTORS}

The precursor proteins that are synthesized on free cytoplasmic ribosomes must have a method of recognizing the organelle for which they are intended and a method of entering or crossing a membrane that is normally impermeable to proteins. The most logical mechanism for such a process is to have specific receptors in the outer membrane of the organelle that can both bind the precursor and mediate its transfer.

The evidence for the presence of a specific receptor in the outer mitochondrial membrane is strongest in the case of cytochrome $c$. The presence of specific saturable binding sites is indicated by the following data. Excess unlabeled apocytochrome $c$ can compete with labeled apocytochrome $c$ and inhibit its transfer into the mitochondria (Hennig and Neupert, 1981). Deuterohemin, an analog of the natural prosthetic group protohemin lacking the vinyl groups necessary for covalent attachment to the apoprotein, inhibits transfer but not binding. In the presence of deuterohemin, radioactive apocytochrome $c$ bound to Neurospora mitochondria can be displaced by excess unlabeled apocytochrome $c$ from Neurospora (Hennig and Neupert, 1981). Apocytochrome $c s$ from other species compete less effectively in a manner that parallels their sequence homology with the native Neurospora protein, with an apocytochrome $c$ from a bacterium (Paracoccus denitrificans) not 
able to compete for the binding sites at all (B. Hennig and W. Neupert, unpublished observations). If mitochondria with radiolabeled apocytochrome $c$ bound in the presence of deuterohemin are isolated, washed, and placed in a medium containing protohemin, the natural prosthetic group, the apocytochrome $c$ is converted to holocytochrome $c$ and transferred into the mitochondria (Hennig and Neupert, 1981). This shows that the apocytochrome $c$ is initially bound to a location on the outside of the mitochondria from which it can be displaced by externally added unlabeled apocytochrome $c$, yet it is bound to a location from which it can be transferred into the mitochondria when the inhibition by deuterohemin is relieved.

Detailed binding studies have been carried out using $\left[{ }^{14} \mathrm{C}\right]$ apocytochrome $c$ prepared by reductive methylation $(H$. Köhler, B. Hennig and W. Neupert, unpublished observations). The binding of labeled apocytochrome $c$ to whole mitochondria gives a biphasic Scatchard plot with about 90 pmoles of highaffinity binding sites $\left(K_{d}=10^{-7} \mathrm{M}\right)$ per $\mathrm{mg}$ of mitochondrial protein. This is a very large number considering the low protein content of the outer mitochondrial membrane. In fact, the only outer membrane protein present in sufficient quantity to explain the number of binding sites found is the porin (Freitag et al., 1982a). Studies are now under way to determine whether the porin could be the receptor for apocytochrome $c$.

The outer membrane of mitochondria also does not appear to have enough proteins for there to bo a separate receptor for each of the many different cytoplasmically synthesized proteins that must be bound and imported. However, efforts to find another protein that uses the same receptor as cytochrome $c$ have proved fruitless. In experiments using Neurospora mitochondria and radioactive precursor proteins synthesized in reticulocyte lysates, excess unlabeled apocytochrome $c$, at a concentration sufficient to inhibit the import of radioactive cytochrome $c$, had no effect on the transfer of the ADP/ATP carrier, subunit 9 of the oligomycin-sensitive ATPase, cytochrome $c_{1}$, subunit $\mathrm{V}$ of the cytochrome $b c_{1}$ complex, or the outer membrane porin (Zimmermann et al., 1981; Teintze et al., 1982; M. Teintze, H. Freitag, and W. Neupert, unpublished observations).

Although studies of binding to putative receptors by precursors of mitochondrial proteins other than cytochrome $c$ are hampered by the fact that the precursors cannot be obtained in sufficient quantity to saturate the binding, there is nevertheless some evidence for the existence of receptors that may be involved in the transfer of the ADP/ATP carrier and that of subunit 9 of the oligomycin-sensitive ATPase. Treatment of Neurospora mitochondria with 
trypsin prior to incubation with the reticulocyte lysate containing the precursors blocks the import of ATPase subunit 9, indicating that a protein in the outer membrane is probably involved in its transfer (B. Schmidt and W. Neupert, unpublished observations). Also, the precursors to both proteins can be bound to mitochondria in the presence of antimycin $\mathrm{A}$ and oligomycin, which break down the membrane potential (see Section 5) and thereby prevent transfer. The bound precursors can be degraded by adding a protease such as proteinase $\mathrm{K}$. However, if the mitochondria with the bound precursors are reisolated, washed, and resuspended in a medium containing $N, N, N^{\prime}, N^{\prime}$ tetramethylphenylenediamine (TMPD) and ascorbic acid, which reenergize the mitochondria, the precursors are transferred to a protease-resistant location in the mitochondria and converted to their mature forms (as determined by carboxyatractyloside (CAT) binding ability for the ADP/ATP carrier and by processing to the size of the mature protein for ATPase subunit 9) (M. Schleyer, B. Schmidt, and W. Neupert, unpublished observations). These results indicate that the precursors were bound to a location on the outside of the mitochondria, probably to a protein, from which they could then be imported when the membrane potential was restored.

The precursor of the outer membrane porin from Neurospora synthesized in a reticulocyte lysate in the presence of $\left[{ }^{35} \mathrm{~S}\right]$ methionine binds to mitochondria rapidly at $4^{\circ} \mathrm{C}$ but is transferred only very slowly. If the mitochondria are reisolated after a short incubation with precursor at $4^{\circ} \mathrm{C}$ and resuspended in unlabeled reticulocyte lysate at $25^{\circ} \mathrm{C}$, the radioactive porin is inserted into the outer membrane and becomes protease-resistant like the mature protein (H. Freitag and W. Neupert, unpublished observations).

\section{TRANSFER OF MANY PROTEINS REQUIRES A MEMBRANE POTENTIAL}

The posttranslational transfer of many cytoplasmically synthesized proteins into mitochondria is energy dependent. This has been shown for the ADP/ATP carrier and subunit 9 of the oligomycin-sensitive ATPase; cytochrome $b_{2}$; cytochrome $c_{1}$; subunits I, II, V, and VII of the cytochrome $b c_{1}$ complex; and ornithine carbamoyltransferase in in vitro transfer experiments (Table I). In addition, the transfer of subunits $\alpha, \beta$, and $\gamma$ of $F_{1}$-ATPase, ATPase subunit 9 , cytochrome $b_{2}$, cytochrome $c_{1}$, subunit V of the cytochrome 
$b c_{1}$ complex, and superoxide dismutase has been shown to be energy dependent using in vivo pulse-labeling experiments (Table I). In most of these experiments, uncouplers or ionophores were used to break down the potential across the mitochondrial inner membrane and this resulted in an inhibition of protein transport and proteolytic processing. The absence of a membrane potential, however, also leads to a depletion of the intramitochondrial ATP because the oligomycin-sensitive ATPase tries to compensate by pumping out protons (Stigall et al., 1979; Scarpa, 1979). This ATPase activity is strongly inhibited by oligomycin (Schleyer et al., 1982). In order to determine whether it is the membrane potential or ATP that is required for the import of these proteins into mitochondria, the transfer has been studied in vitro under conditions in which either the membrane potential is broken down but ATP is still present or the membrane potential is maintained but the intramitochondrial ATP is depleted. The transfer of the ADP/ATP carrier and ATPase subunit 9 was studied in a system employing isolated Neurospora mitochondria suspended in the postribosomal supernatant of a reticulocyte lysate that had been incubated with Neurospora RNA and $\left[{ }^{35}\right.$ S $]$ methionine (Schleyer et al., 1982). The uncouplers and protonophores carbonylcyanide $m$-chlorophenylhydrazone (CCCP) and dinitrophenol were used. Both with and without oligomycin and ATP the transfer of the precursor proteins and the processing of ATPase subunit 9 were inhibited, but binding of the precursors to the mitochondria still occurred. Valinomycin, $\mathrm{K}^{+}$ionophore that breaks down the membrane potential in the presence of high $\mathrm{K}^{+}$concentrations like that present in the reticulocyte lysate $(90 \mathrm{mM})$, gave the same results as CCCP. In both of these experiments the intramitochondrial ATP level was high, as demonstrated by the protein synthesis on the mitochondrial ribosomes (Schleyer et al., 1982). This is due to three factors: (1) the inhibition of ATPase by oligomycin, (2) the high ATP concentration in the lysate, and (3) the absence of a membrane potential, which causes the external and internal ATP pools to equilibrate via the ADP/ATP carrier (Heldt et al., 1972). In another experiment carboxyatractyloside, which blocks the ADP/ATP carrier, was added together with oligomycin to deplete the intramitochondrial ATP pool while leaving the membrane potential intact (Schleyer et al., 1982). Under these conditions there was no inhibition of transfer or proteolytic processing. The same experiments have since been carried out on cytochrome $c_{1}$ and subunits $\mathrm{I}, \mathrm{V}$, and VII of the cytochrome $b c_{1}$ complex (Teintze et al., 1982). In each case the same pattern of response to inhibitors was observed. These observations show that the membrane potential, and not ATP, is the source of energy for 
the import of precursor proteins into mitochondria. The ionophore nigericin, which exchanges $\mathrm{K}^{+}$for $\mathrm{H}^{+}$and causes a breakdown of the proton gradient without affecting the membrane potential (Graven et al., 1966; Pressman, 1976), did not inhibit the transfer of the ADP/ATP carrier or the transfer and processing of ATPase subunit 9 (Schleyer et al., 1982). Apparently it is the electrical membrane potential and not just the proton gradient that is required.

The energy-dependent transfer of precursor proteins can also be blocked by a combination of antimycin $\mathrm{A}$, an inhibitor of the electron transport chain, and oligomycin to inhibit the oligomycin-sensitive ATPase, thus blocking both pathways for generating a membrane potential. This inhibition can be relieved by the addition of ascorbate and TMPD, which feed electrons directly into the cytochrome oxidase, i.e., after the site of inhibition of antimycin A, and allow the membrane potential to be reestablished. If precursors are bound in the presence of antimycin $\mathrm{A}$ and oligomycin and the mitochondria are reisolated and resuspended in a medium containing TMPD and ascorbate but no additional precursor, the bound precursors are imported and converted to the mature proteins (Schleyer et al., 1982).

Schatz and co-workers studied the transfer of subunits $\alpha, \beta$, and $\gamma$ of $\mathrm{F}_{1}$-ATPase, cytochrome $c_{1}$, and subunit $\mathrm{V}$ of the cytochrome $b c_{1}$ complex in vivo and rho- mutants of $S$. cerevisiae and came to the conclusion that ATP was required rather than the membrane potential (Nelson and Schatz, 1979). $R h o^{-}$mutants have mitochondria deficient in protein synthesis and thus lack both a functional respiratory chain and functional oligomycin-sensitive ATPase (Lloyd, 1974). These mitochondria should therefore not be able to generate a membrane potential by respiration or ATP hydrolysis. Nevertheless, $r h o^{-}$cells contain mitochondria that import and process cytoplasmically synthesized proteins. Thus it was concluded that ATP obtained from the cytoplasm via the ADP/ATP carrier (Subik et al., 1974) must be providing the necessary energy (Nelson and Schatz, 1979). Later studies on in vitro import of cytochrome $b_{2}$ into isolated yeast mitochondria, however, suggested that this protein requires an electrochemical gradient for import (Gasser et $a l ., 1982)$. The situation in the $r h o^{-}$mutants remains unclear; however, one possibility is that the import of ATP coupled to the export of ADP generates a small membrane potential in the mitochondria because it is an electrogenic process (Scarpa, 1979).

Both cytochrome $c$ and the porin of the outer mitochondrial membrane do not require energy for their import (Zimmermann et al., 1981; Freitag et al., 1982b). Both are not proteolytically processed, but neither is the ADP/ 
ATP carrier, which nevertheless requires energy for import. The reason for the lack of an energy requirement for import of cytochrome $c$, which is located in the intermembrane space, and the outer membrane porin may be the fact that neither needs to be transferred into or across the inner mitochondrial membrane. Cytochrome $b_{2}$ in yeast, an intermembrane space enzyme that does require an inner membrane potential for import and processing, is thought to cross and recross the inner mitochondrial membrane before reaching its functional site. The same may be true for cytochrome $c_{1}$, which is located with its major domain on the cytoplasmic side of the inner membrane (Gasser et al., 1982).

\section{PROTEOLYTIC PROCESSING ENZYMES}

There have been a number of reports recently describing proteolytic enzymes isolated from mitochondria that process precursors of mitochondrial proteins to the apparent molecular weights of the mature proteins. Böhni $e t$ al. (1980) discovered a protease activity in hypotonic extracts of yeast and rat liver mitochondria that apparently correctly processed the precursor of yeast $F_{1}$-ATPase subunits $\alpha, \beta$, and $\gamma$ and cytochrome $c$ oxidase subunit $V$ synthesized in an in vitro cell-free system. All four of these proteins are synthesized as larger precursors on cytoplasmic ribosomes and then posttranslationally transferred to their functional sites in the mitochondrial matrix or inner membrane (Maccecchini et al., 1979a; Lewin et al., 1980). Both yeast and rat liver processing enzyme activities could be inhibited by the metal chelators $o$-phenanthroline and ethylenediaminetetraacetic acid (EDTA) but not by serine protease inhibitors; the processing activity of the rat liver mitochondria fractionated with marker enzymes of the matrix space (Böhni et al., 1980). The yeast mitochondrial protease apparently also processes the precursors of cytochrome $c_{1}$ and cytochrome $b_{2}$, an intermembrane space enzyme, but only to their intermediate forms (Gasser et al., 1982). The proteolytic processing enzyme of the yeast mitochondria was further purified and characterized by McAda and Douglas (1982). They showed that the enzyme that processes subunit $2(\beta)$ of the $F_{1}$-ATPase in yeast was a metalloendoprotease complex of $M_{r} 115,000$ with a pH optimum between 7 and 8 . Its activity was inhibited by EDTA and $o$-phenanthroline, and could be restored with excess $\mathrm{Co}^{2+}$ or $\mathrm{Mn}^{2+}$. 
In studies on rat liver mitochondria, two different groups have isolated a protease from the mitochondrial matrix that processes the precursor of ornithine carbamoyltransferase (Miura et al., 1982; Conboy et al., 1982). The protease characterized by Miura et al. (1982) had an $M_{r}$ of 108,000 and was inhibited by the metal chelators EDTA, $o$-phenanthroline, and zincon. It processed the precursor of ornithine carbamoyltransferase $\left(M_{r} 39,400\right)$ to an intermediate form $\left(M_{r} 37,000\right)$ but not to the size of the mature subunit $\left(M_{r} 36,000\right)$. This processing enzyme was also isolated from the mitochondrial matrix of rat kidney, spleen, heart, and ascites tumor cells, all of which lack ornithine carbamoyltransferase, and therefore probably has a broader specificity. The enzyme isolated by Conboy et al. (1982) converts pre-ornithine carbamoyltransferase to the apparent molecular weight of the mature subunit as well as to the intermediate form. It was shown to require $\mathrm{Zn}^{2+}, \mathrm{Co}^{2+}$, or $\mathrm{Mn}^{2+}$ for activity but still processed the precursor of ornithine carbamoyltransferase to the intermediate form in the absence of these metal ions.

Considering the common characteristics of all the precursor-processing enzymes described above, it would be interesting to know whether there is only one such enzyme, whether this enzyme can process precursors other than those described above, and whether the same enzyme can be found in the mitochondria of other species. Sequencing analyses will be required, however, to show that any such protease actually processes the precursors correctly.

\section{DIFFERENT ORGANISMS HAVE CLOSELY RELATED TRANSFER MACHINERIES}

Labeled precursors to Neurospora mitochondrial proteins synthesized in a reticulocyte lysate cell-free system can be imported into isolated mitochondria from other organisms and are converted to their mature forms. The transfer of the Neurospora ADP/ATP carrier and ATPase subunit 9 into rat liver mitochondria requires an electrochemical gradient across the inner mitochondrial membrane just like the corresponding transfer into Neurospora mitochondria (Schleyer et al., 1982). Both proteins were transferred into proteaseresistant locations and the ATPase subunit 9 was processed to the molecular weight of the mature subunit. Similar results have been obtained with the transfer of these proteins into yeast and guinea pig heart mitochondria (B. Schmidt, M. Schleyer, and W. Neupert, unpublished observations). The Neu- 
rospora ADP/ATP carrier was shown to be in its functional form after transfer into yeast mitochondria on the basis of its ability to bind CAT, which the precursor does not. The ATPase subunit 9 precursor was processed correctly by the yeast mitochondria during transfer, as shown by radiosequencing analysis (B. Schmidt, B. Hennig, and W. Neupert, unpublished observations). This is especially interesting since the yeast ATPase subunit 9 is encoded on the mitochondrial genome and synthesized inside the mitochondria without an additional sequence (Sebald and Wachter, 1978; Macino and Tzagoloff, 1979; Hensgens et al., 1979). Yeast mitochondria therefore do not have to import and process a cytoplasmically made ATPase subunit 9 precursor in vivo, but the mechanism for doing so must be conserved. The precursor of subunit $\mathrm{V}\left(\mathrm{Fe} / \mathrm{S}\right.$ protein) of the Neurospora cytochrome $b c_{1}$ complex is also imported into yeast mitochondria and processed to the molecular weight of the mature protein when an inner membrane potential is present (Teintze et al., 1982). Recently the Neurospora outer membrane porin precursor was also successfully imported into rat liver and yeast mitochondria $(\mathrm{H}$. Freitag and W. Neupert, unpublished observations).

The precursor of rat liver ornithine carbamoyltransferase is also imported and processed to the correct molecular weight by mouse liver and kidney mitochondria (Morita et al., 1982).

Combined with the data discussed in the previous section showing that a protease isolated from rat liver processes yeast precursors (Böhni et al., 1980), these results suggest that the mechanism for importing cytoplasmically synthesized precursors into mitochondria including the proteins mediating recognition, import, and processing has been highly conserved in evolution.

\section{FUNCTIONAL ASSEMBLY OF MITOCHONDRIAL ENZYME COMPLEXES}

Only a very small number of mitochondrial proteins are encoded on the mitochondrial genome (Tzagoloff et al., 1979). Most of these proteins are subunits of enzyme complexes that also contain subunits synthesized in the cytoplasm, such as the oligomycin-sensitive ATPase, cytochrome $c$ oxidase, and the cytochrome $b c_{1}$ complex. The question of how the synthesis of subunits in the mitochondrial and the cytoplasm is regulated so that stoichiometric 
amounts of each subunit are available for assembly into a functional complex remains unanswered. It is known only that inhibition of mitochondrial protein synthesis has no gross effect on the production of cytoplasmically synthesized subunits. For instance, Neurospora cells can be grown for many generations in the presence of chloramphenicol, which inhibits mitochondrial but not cytoplasmic protein synthesis. The cells still make mitochondria, and even though they contain very little cytochrome $b$ (a mitochondrial gene product), cytochrome $c_{1}$ is still synthesized in the cytoplasm, imported into the mitochondria in normal quantities, and proteolytically processed to the mature form, although it cannot be assembled into a cytochrome $b c_{1}$ complex (Weiss and Kolb, 1979).

Another problem that has not been completely solved is to demonstrate that precursors of nuclear-coded subunits synthesized in a cell-free system and then transferred into isolated mitochondria are actually assembled into functional complexes. Following transfer in vitro of radiolabeled Neurospora precursor into mitochondria, the labeled subunit 9 of the oligomycin-sensitive ATPase can be precipitated with antibodies directed against the $F_{1}$ portion of the complex (B. Schmidt and W. Neupert, unpublished observations). These antibodies will not precipitate isolated ATPase subunit 9, so the imported subunits must be assembled with the $F_{1}$ subunits, but one cannot rule out a subunit exchange during the immunoprecipitation process.

After transfer in vitro, the precursor to the ADP/ATP carrier acquires certain characteristics of the dimeric functional carrier (M. Schleyer and W. Neupert, unpublished observations). It binds CAT, as demonstrated by protection against protease activity; CAT is bound by the dimeric carrier in the membrane (Klingenberg et al., 1979) but not by the precursor in the reticulocyte lysate, or the precursor bound to mitochondria in the presence of energy inhibitors. Also, both the mature assembled ADP/ATP carrier and the protein transferred in vitro pass through hydroxyapatite columns, whereas the precursor binds.

Assembly in vitro has been clearly demonstrated for ribulose-1,5-bisphosphate carboxylase in chloroplasts (Chua and Schmidt, 1978). The small subunit of this enzyme is made on free cytoplasmic ribosomes and transferred into the chloroplast, where it is proteolytically processed and assembled with the large subunit, which is made in the chloroplast. After synthesis and transfer in vitro it was shown that $80 \%$ of the labeled small subunit had been assembled with the large subunit to form the holoenzyme, as determined by density gradient centrifugation and electrophoresis on nondenaturing gels. 
3 Binding to Receptor

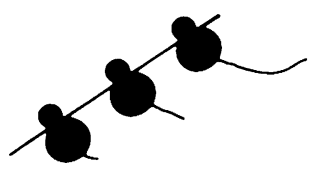

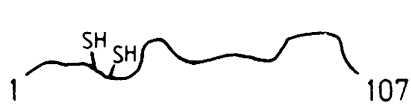

Apocytochrome c
Inner Membrane

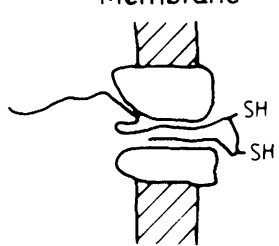

4 Attachment of Heme by a Lyase

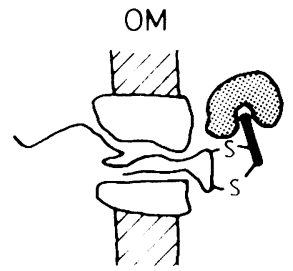

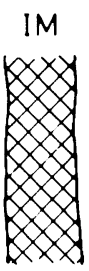

5 Refolding and Transfer
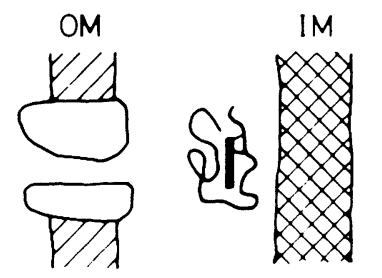

Holocytochrome c

FIGURE 1. Proposed assembly mechanism for cytochrome $c$. 


\section{POSSIBLE ASSEMBLY PATHWAYS}

The mitochondrial protein whose biogenesis is best understood is cytochrome $c$. This enzyme is synthesized as apocytochrome $c$ in the cytoplasm and must cross the outer mitochondrial membrane and gain a covalently attached heme group to reach its functional location in the intermembrane space as holocytochrome $c$ bound to the cytoplasmic face of the inner membrane. A schematic representation of the mechanism by which this is thought to occur is shown in Figure 1. Apocytochrome $c$ is synthesized on free cytoplasmic ribosomes with the same amino acid sequence as the mature protein (Zimmermann et al., 1979a). It then binds to specific sites on the outside of the mitochondria before being transferred across the outer membrane in conjunction with the covalent attachment of a heme group via two cysteine residues (Hennig and Neupert, 1981). When labeled apocytochrome $c$ is bound to its receptor, it is still accessible to the outside since it can be displaced specifically by unlabeled apocytochrome $c$. It must also be accessible to heme and the enzyme that attaches it to the protein. Probably the portion of the apocytochrome $c$ to which the heme must be attached extends into the intermembrane space so that the change in conformation induced by attachment of the heme group pulls the rest of the protein into the intermembrane space. This mechanism does not require the presence of any type of "signal" sequence in the protein; the receptor recognizes the conformation of apocytochrome $c$ but not holocytochrome $c$, and the change in conformation upon attachment of the heme group is probably responsible for both the transfer across the membrane and for the irreversibility of the import process. The portion of apocytochrome $c$ responsible for recognition may be located in the highly conserved sequence around residues $70-80$, which is rather hydrophobic. This was concluded from competition experiments with fragments of apocytochrome $c$ (Matsuura et al., 1981; B. Hennig and W. Neupert, unpublished observations).

The simplest mechanism in mitochondrial membrane assembly should be the insertion of cytoplasmically synthesized proteins into the outer membrane, since such proteins do not have to cross one or more membranes to reach the functional site. The only well-characterized protein of the outer mitochondrial membrane whose biogenesis has been studied is the porin. The outer membrane porin is synthesized on free cytoplasmic ribosomes as a watersoluble precursor that has the same molecular weight as the mature protein 
(Freitag et al., 1982b). Also, in this case, specific binding of the precursor precedes its insertion into the membrane. Isolated detergent-solubilized mature porin will insert into artificial lipid bilayers to form pores (Freitag et al., 1982a). The water-soluble precursor form can be regenerated from the isolated porin by removing all the detergent. This lipid-free form can compete with in-vitro-synthesized precursor for binding and transfer into the mitochondrial outer membrane, but it will not insert into artificial lipid bilayers until sterols are added (H. Freitag, R. Benz, and W. Neupert, unpublished observations). This suggests that the composition of the membrane may be important for the recognition or insertion process and that no covalent modification is necessary for the assembly of the porin.

The insertion of proteins into the outer mitochondrial membrane is topologically similar to the insertion of proteins into the plasma membrane or microsomal membranes. Posttranslational transfer into these compartments has also been observed. Cytochrome $b_{5}$ and cytochrome $b_{5}$ reductase are synthesized on free polysomes without any additional sequences (Okada et $a l ., 1982)$ and the large unglycosylated subunit of $\mathrm{Na}^{+}, \mathrm{K}^{+}$-ATPase is also made on free polysomes before assembly into the plasma membrane, although the small glycosylated subunit is synthesized in the rough endoplasmic reticulum (Sabatini et al., 1982).

The transfer of proteins from the cytoplasm to the inner mitochondrial membrane or the matrix space is more complicated, since it involves crossing the outer membrane, the aqueous intermembrane space, and then the inner membrane. This process may occur via some type of contact site between the inner and outer membranes (Figure 2). Almost all precursors of inner membrane and matrix proteins whose sites of synthesis have been investigated are made on free polysomes (Table I). In most cases a cytoplasmic precursor pool has been observed and the import into mitochondria is posttranslational. The transfer of proteins into the inner membrane or the matrix requires energization of the mitochondria (Table I) and for a number of inner membrane proteins it has been shown that it is the electrochemical gradient across the inner membrane that drives the import and processing (Schleyer et al., 1982; Teintze et al., 1982). Most inner membrane and matrix proteins are made as larger precursors, whose additional sequences are proteolytically cleaved sometime during the transfer and assembly process. A metal-dependent endoprotease that processes some of these precursors to their mature size has been isolated from the mitochondrial matrix by a number of groups. As might 


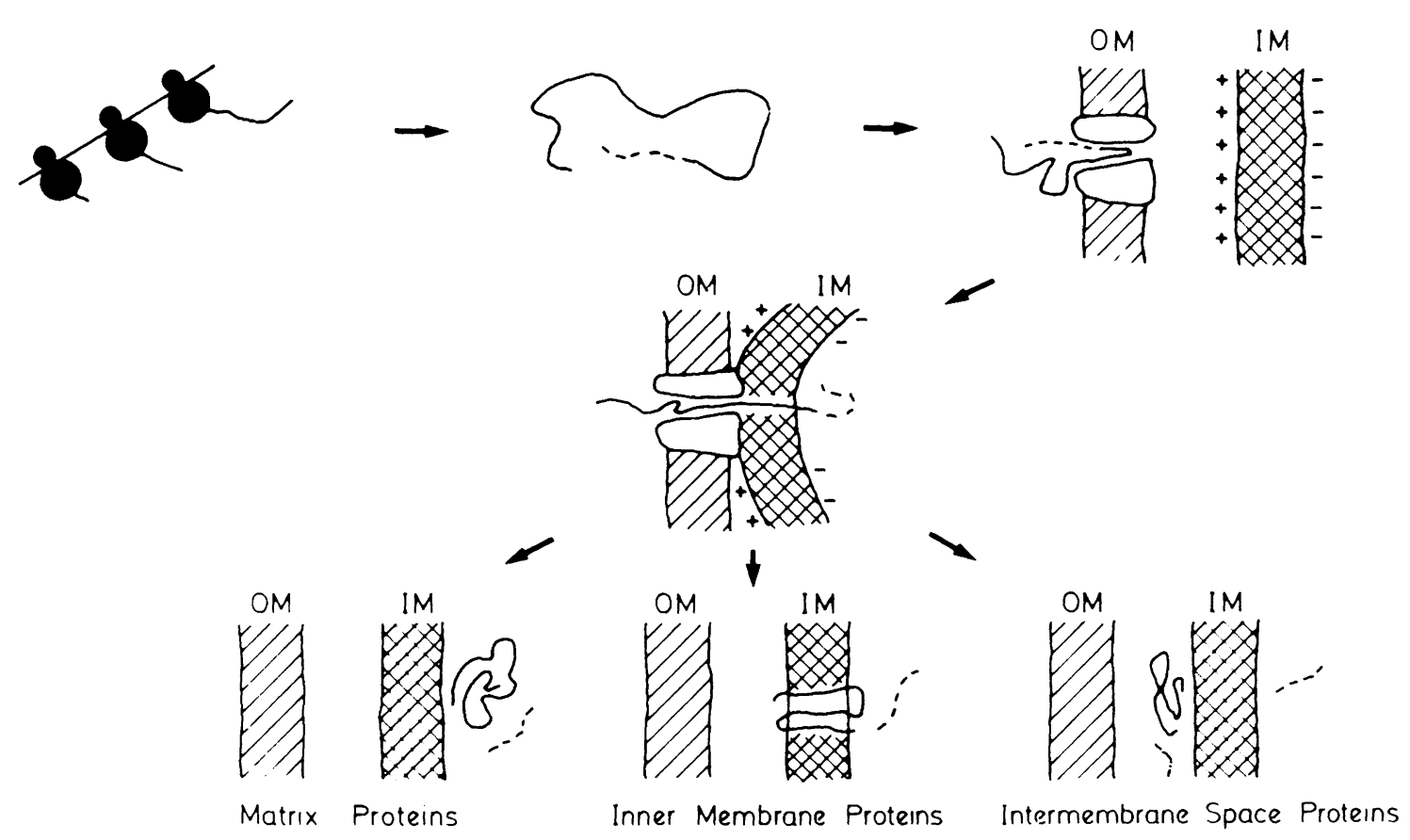

FIGURE 2. Hypothetical pathway for assembly of mitochondrial proteins requiring energy for transfer. The dashed and dotted lines represent portions of the sequence that are removed during transfer. OM, outer membrane; IM, inner membrane. 
be expected, the proteins correctly processed by this enzyme are located in the matrix or on the matrix side of the inner membrane.

The function of the additional sequences on the precursors is not altogether clear. They probably serve to keep the precursors in a different (i.e., water soluble) conformation outside the mitochondria, and removal of the extra sequences inside the mitochondria probably makes the assembly process irreversible. The additional sequence may also be important for the recognition of the precursor by a receptor on the mitochondrial surface.

Cytochrome $c_{1}$ (located on the cytoplasmic side of the inner membrane) and cytochrome $b_{2}$ (located in the intermembrane space), are both processed in two separate steps during transfer. The second processing step requires heme for cytochrome $c_{1}$, which has a covalently linked heme group, but not for cytochrome $b_{2}$, whose heme group is not covalently attached (Gasser et al., 1982). Both precursors are processed to the apparent molecular weight of their intermediate forms by the protease found in the matrix. It was therefore suggested that the polypeptides initially extend into the matrix space during their transfer, so that a portion of the sequence can be removed by the matrix protease. Following this step the intermediate form would return to the intermembrane space side of the inner membrane and be processed again by a different enzyme (Gasser et al., 1982). Both cytochrome $c_{1}$ and cytochrome $b_{2}$ require a membrane potential for the first part of the transfer process (Teintze et al., 1982; Gasser et al., 1982), and the processing of cytochrome $c_{1}$ from the intermediate form to the mature size also requires energy (Teintze et al., 1982). It is possible that other proteins share this two-step processing mechanism, but their intermediates may be so short-lived that they have escaped detection.

Insertion into or transfer across the inner membrane evidently requires an intact membrane potential, even for proteins like the ADP/ATP carrier that are not proteolytically processed (Schleyer et al., 1982). The energy dependence of the import of cytochrome $b_{2}$ into the intermembrane space further supports the idea that this enzyme makes a "detour" through the inner membrane to reach its functional location.

The least-understood step in the transfer process at this time is how the proteins get through or into the membrane after recognition by a receptor on the mitochondria. They cannot be "pushed" through by polypeptide chain elongation as they may be in cotranslational transport, so some feature of the protein sequence must result in this translocation. So far, however, no com- 
mon structure has been found among the many imported mitochondrial proteins that would suggest how this might occur.

\section{REFERENCES}

Autor, A. P., 1982, Biosynthesis of mitochondrial manganese superoxide dismutase in Saccharomyces cerevisiae. Precursor form of mitochondrial superoxide dismutase made in the cytoplasm, J. Biol. Chem. 257:2713-2718.

Blobel, G., and Dobberstein, B., 1975, Transfer of proteins across membranes, J. Cell Biol. 67:835-851.

Böhni, P., Grasser, S., Leaver, C., and Schatz, G., 1980, A matrix-localized mitochondrial protease processing cytoplasmically-made precurors to mitochondrial proteins, in: The Organization and Expression of the Mitochondrial Genome (A. Kroon and C. Saccone, eds.) Elsevier, Amsterdam, pp. 423-433.

Chua, N.-H., and Schmidt, G. W., 1978, Post-translational transport into intact chloroplasts of a precursor to the small subunit of ribulose-1,5-bisphosphate carboxylase, Proc. Natl. Acad. Sci. USA 75:6110-6114.

Chua, N.-H., and Schmidt, G. W., 1979, Transport of proteins into mitochondria and chloroplasts, J. Cell Biol. 81:461-483.

Conboy, J. G., and Rosenberg, L. E., 1981, Post-translational uptake and processing of in vitro synthesized ornithine transcarbamoylase precursor by isolated rat liver mitochondria, Proc. Natl. Acad. Sci. USA 78:3073-3077.

Conboy, J. G., Fenton, W. A., and Rosenberg, L. E., 1982, Processing of pre-ornithine transcarbamylase requires a zinc-dependent protease localized to the mitochondrial matrix, Biochem. Biophys. Res. Commun. 105:1-7.

Côte, C., Solioz, M., and Schatz, G., 1979, Biogenesis of the cytochrome $b c_{1}$ complex of yeast mitochondria. A precursor form of the cytoplasmically made subunit V, J. Biol. Chem. 254:1437-1439.

DuBois, R. N., Simpson, E. R., Tuckey, J., Lambeth, J. D., and Waterman, M. R., 1981, Evidence for a higher molecular weight precursor of cholesterol side-chain-cleavage cytochrome P-450 and induction of mitochondrial and cytosolic proteins by corticotropin in adult bovine adrenal cells, Proc. Natl. Acad. Sci. USA 78:1028-1032.

Freitag, H., Neupert, W., and Benz, R., 1982a, Purification and characterization of a pore protein of the outer mitochondrial membrane from Neurospora crassa, Eur. J. Biochem. 123:629-636.

Freitag, H., Janes, M., and Neupert, W., 1982b, Biosynthesis of mitochondrial porin and insertion into the outer mitochondrial membrane of Neurospora crassa, Eur. J. Biochem. 126:197-202.

Gasser, S. M., Ohashi, A., Daum, G., Böhni, P. C., Gibson, J., Reid, G. A., Yonetani, T., and Schatz, G., 1982, Imported mitochondrial proteins cytochrome $b_{2}$ and cytochrome $c_{1}$ are processed in two steps, Proc. Natl. Acad. Sci. USA 79:267-271.

Graven, S. N., Estrada-O., S., and Lardy, H. A., 1966, Alkali metal cation release and respiratory inhibition induced by nigericin in rat liver mitochondria, Proc. Natl. Acad. Sci. USA 56:654-658. 
Hallermayer, G., Zimmermann, R., and Neupert, W., 1977, Kinetic studies on the transport of cytoplasmically synthesized proteins into mitochondria in intact cells of Neurospora crassa, Eur. J. Biochem. 81:523-532.

Harmey, M. A., and Neupert, W., 1979, Biosynthesis of mitochondrial citrate synthase in Neurospora crassa, FEBS Lett. 108:385-389.

Heinrich, P. C., 1982, Proteolytic processing of polypeptides during the biosynthesis of subcellular structures, Rev. Physiol. Biochem. Pharmacol. 93:115-187.

Heldt, H. W., Klingenberg, M., and Milovancev, M., 1972, Differences between the ATP/ADP ratios in the mitochondrial matrix and in the extramitochondrial space, Eur. J. Biochem. 30:434-440.

Hennig, B., and Neupert, W., 1981, Assembly of cytochrome $c$. Apocytochrome $c$ is bound to specific sites on mitochondria before its conversion to holocytochrome $c$, Eur. J. Biochem. 121:203-212.

Hensgens, L. A. M., Grivell, L. A., Borst, P., and Bos, J. L., 1979, Nucleotide sequence of the mitochondrial gene for subunit 9 of yeast ATPase complex, Proc. Natl. Acad. Sci. USA 76:1663-1667.

Jackson, R. C., and Blobel, G., 1977, Posttranslational cleavage of presecretory proteins with an extract of rough microsomes from dog pancreas containing signal peptidase activity, Proc. Natl. Acad. Sci. USA 74:5598-5602.

Klingenberg, M., Aquila, H., and Riccio, P., 1979, Isolation of functional membrane proteins related to or identical with the ADP,ATP carrier of mitochondria, Methods Enzymol. 56:407-414.

Korb, H., and Neupert, W., 1978, Biogenesis of cytochrome $c$ in Neurospora crassa. Synthesis of apocytochrome $c$, transfer to mitochondria and conversion to holocytochrome $c$, Eur. J. Biochem. 91:609-620.

Kreibich, G., Czako-Graham, M., Grebenau, R., Mok, W., Rodriguez-Boulan, E., and Sabatini, D. D., 1978, Characterization of the ribosomal binding site in rat liver rough microsomes: Ribophorins I and II, two integral membrane proteins related to ribosome binding, $J$. Supramol. Struct. 8:279-302.

Lewin, A. S., Gregor, I., Mason, T. L., Nelson, N., and Schatz, G., 1980, Cytoplasmically made subunits of yeast mitochondrial $F_{1}$-ATPase and cytochrome $c$ oxidase are synthesized as individual precursors, not as polyproteins, Proc. Natl. Acad. Sci. USA 77:3998-4002.

Lloyd, D., 1974, The Mitochondria of Microorganisms, Academic Press, London, pp. 82-158.

McAda, P. C., and Douglas, M. G., 1982, A neutral metallo endoprotease involved in the processing of an $F_{1}$-ATPase subunit precursor in mitochondria, J. Biol. Chem. 257:3177-3182.

Maccecchini, M.-L., Rudin, Y., Blobel, G., and Schatz, G., 1979a, Import of proteins into mitochondria: Precursor forms of the extramitochondrially made $F_{1}$-ATPase subunits in yeast, Proc. Natl. Acad. Sci. USA 76:343-347.

Maccecchini, M.-L., Rudin, Y., and Schatz, G., 1979b, Transport of proteins across the mitochondrial outer membrane. A precursor form of the cytoplasmically made intermembrane enzyme cytochrome $c$ peroxidase, J. Biol. Chem. 254:7468-7471.

Macino, G., and Tzagoloff, A., 1979, Assembly of the mitochondrial membrane system. The DNA sequence of a mitochondrial ATPase gene in Saccharomyces cerevisiae, J. Biol. Chem. 254:4617-4623.

Matsuura, S., Arpin, M., Hannum, C., Margoliash, E., Sabatini, D. D., and Morimoto, T., 1981, In vitro synthesis and post-translational uptake of cytochrome $c$ into isolated mitochondria: Role of a specific addressing signal in the apocytochrome, Proc. Natl. Acad. Sci. USA 78:4368-4372. 
Meyer, D. I., and Dobberstein, B., 1980, Identification and characterization of a membrane component essential for the translocation of nascent protein across the membrane of the endoplasmic reticulum, J. Cell Biol. 87:503-508.

Meyer, D. I., Krause, E., and Dobberstein, B., 1982, Secretory protein translocation across membranes: the role of the "docking protein," Nature 297:647-650.

Michel, R., Wachter, E., and Sebald, W., 1979, Synthesis of a larger precursor for the proteolipid subunit of the mitochondrial ATPase complex of Neurospora crassa in a cell-free wheat germ system, FEBS Lett. 101:373-376.

Mihara, K., and Blobel, G., 1980, The four cytoplasmically made subunits of yeast mitochondrial cytochrome $c$ oxidase are synthesized individually and not as a polyprotein, Proc. Natl. Acad. Sci. USA 77:4160-4164.

Mihara, K., Omura, T., Harano, T., Brenner, S., Fleischer, S., Rajagopalan, K. V., and Blobel, G., 1982, Rat liver L-glutamate dehydrogenase, D- $\beta$-hydroxybutyrate dehydrogenase, and sulfite oxidase are each synthesized as larger precursors by cytoplasmic free polysomes, $J$. Bid. Chem. 257:3355-3358.

Miura, S., Mori, M., Amaya, Y., and Tatibana, M., 1982, A mitochondrial protease that cleaves the precursor of ornithine carbamoyltransferase. Purification and properties, Eur. J. Biochem. 122:641-647.

Mori, M., Miura, S., Tatibana, M., and Cohen, P. P., 1979, Cell-free synthesis and processing of a putative precursor for mitochondrial carbamyl phosphate synthetase I of rat liver, Proc. Natl. Acad. Sci. USA 76:5071-5075.

Mori, M., Miura, S., Tatibana, M., and Cohen, P. P., 1980, Processing of a putative precursor of rat liver ornithine transcarbamylase, a mitochondrial matrix enzyme, J. Biochem. 88:1829-1836.

Morita, T., Miura, S., Mori, M., and Tatibana, M., 1982, Transport of the precursor for ratliver ornithine carbamoyltransferase into mitochondria in vitro, Eur. J. Biochem. 122:501-509.

Nabi, N., and Omura, T., 1980, In vitro synthesis of adrenodoxin and adrenodoxin reductase: Existence of a putative large precursor form of adrenodoxin, Biochem. Biophys. Res. Commun. 97:680-686.

Nabi, N., Kominami, S., Takemori, S., and Omura, T., 1980, In vitro synthesis of mitochondrial cytochromes P-450 (scc) and P-450 (11- $\beta$ ) and microsomal cytochrome P-450 (c-21) by both free and bound polysomes isolated from bovine adrenal cortex, Biochem. Biophys. Res. Commun. 97:687-693.

Nelson, N., and Schatz, G., 1979, Energy-dependent processing of cytoplasmically made precursors to mitochondrial proteins, Proc. Natl. Acad. Sci. USA 76:4365-4369.

Neupert, W., and Schatz, G., 1981, How proteins are transported into mitochondria, Trends Biochem. Sci. 6:1-4.

Okada, Y., Frey, A. B., Guenther, T. M., Oesch, F., Sabatini, D. D., and Kreibich, G., 1982, Studies on the biosynthesis of microsomal membrane proteins. Site of synthesis and mode of insertion of cytochrome $b_{5}$, cytochrome $b_{5}$ reductase, cytochrome P-450 reductase and expoxide hydrolase, Eur. J. Biochem. 122:393-402.

Palade, G., 1975, Intracellular aspects of the process of protein synthesis, Science 189:347-358.

Pressman, B. C., 1976, Biological applications of ionophores, Annu. Rev. Biochem. 45:501-530.

Raymond, Y., and Shore, G. C., 1979, The precursor for carbamyl phosphate synthetase is transported to mitochondria via a cytosolic route, J. Biol. Chem. 254:9335-9338.

Raymond, Y., and Shore, G. C., 1980, Kinetics of uptake and processing of the precursor for carbamyl phosphate synthetase by mitochondria in vivo and in vitro, J. Cell Biol. 87:MC1424 (abstr.). 
Sabatini, D. D., Kreibich, G., Morimoto, T., and Adesnik, M., 1982, Mechanisms for the incorporation of proteins in membranes and organelles, J. Cell Biol. 92:1-22.

Sakakibara, R., Huynh, Q. K., Nishida, Y., Watanabe, T., and Wade, H., 1980, In vitro synthesis of glutamic oxaloacetic transaminase isozymes of rat liver, Biochem. Biophys. Res. Commun. 95:1781-1788.

Scarpa, A., 1979, Transport across mitochondrial membranes, in: Membrane Transport in Biology. II. Transport Across Single Biological Membranes (D. C. Tosteson, ed.), SpringerVerlag, Berlin, pp. 263-355.

Schatz, G., 1979, How mitochondria import proteins from the cytoplasm, FEBS Lett. 103:201-211.

Schatz, G., and Mason, T. L., 1974, The biosynthesis of mitochondrial proteins, Annu. Rev. Biochem. 43:51-87.

Schleyer, M., Schmidt, B., and Neupert, W., 1982, Requirement of a membrane potential for the posttranslational transfer of proteins into mitochondria, Eur. J. Biochem. 125:109-116.

Schmelzer, E., and Heinrich, P. C., 1980, Synthesis of a larger precursor for the subunit IV of rat liver cytochrome $c$ oxidase in a cell-free wheat germ system, J. Biol. Chem. 255:7503-7506.

Sebald, W., and Wachter, E., 1978, Amino acid sequence of the putative protonophore of the energy-transducing ATPase complex, in: 29th Moosbach Colloquium: Energy Conservation in Biological Membranes (G. Schäfer and M. Klingenberg, eds.), Springer-Verlag, Berlin, pp. 228-263.

Shore, G. C., Carignan, P., and Raymond, Y., 1979, In vitro synthesis of a putative precursor to the mitochondrial enzyme, carbamyl phosphate synthetase, J. Biol. Chem. 254:3141-3144.

Sonderegger, P., Jaussi, R., and Christen, P., 1980, Cell-free synthesis of a putative precursor of mitochondrial aspartate aminotransferase with higher molecular weight, Biochem. Biophys. Res. Commun. 94:1256-1260.

Sonderegger, P., Jaussi, R., Christen, P., and Gehring, H., 1982, Biosynthesis of aspartate aminotransferase. Both the higher molecular weight precursor of mitochondrial aspartate aminotransferase and the cytosolic isoenzyme are synthesized on free polysomes, J. Biol. Chem. 257:3339-3345.

Stigall, D. L., Galante, Y. M., and Hatefi, Y., 1979, Preparation and properties of complex V, Methods Enzymol. 55:308-315.

Subik, J., Kolarov, J., and Kovac, L., 1974, Bongkrekic acid sensitivity of respiration-deficient mutants and of petite negative species of yeast, Biochim. Biophys. Acta 357:453-456.

Teintze, M., Slaughter, M., Weiss, H., and Neupert, W., 1982, Biogenesis of mitochondrial ubiquinol:cytochrome $c$ reductase (cytochrome $b c$, complex). Precursor proteins and their transfer into mitochondria, J. Biol. Chem. 257:10364-10371.

Tzagoloff, A., Macino, G., and Sebald, W., 1979, Mitochondrial genes and translation products, Annu. Rev. Biochem. 48:419-441.

Walter, P., and Blobel, G., 1981a, Translocation of proteins across the endoplasmic reticulum. II. Signal recognition protein (SRP) mediates the selective binding to microsomal membranes of in-vitro-assembled polysomes synthesizing secretory protein, J. Cell Biol. 91:551-556.

Walter, P., and Blobel, G., 1981b, Translocation of proteins across the endoplasmic reticulum. III. Signal recognition protein (SRP) causes signal sequence-dependent and site-specific arrest of chain elongation that is released by microsomal membranes, J. Cell Biol. 91:557-561.

Walter, P., Jackson, R. C., Marcus, M. M., Lingappa, V. R., and Blobel, G., 1979, Tryptic dissection and reconstitution of translocation activity for nascent presecretory proteins across microsomal membranes, Proc. Natl. Acad. Sci. USA 76:1795-1799.

Walter, P., Ibrahimi, I., and Blobel, G., 1981, Translocation of proteins across the endoplasmic reticulum. I. Signal recognition protein (SRP) binds to in-vitro-assembled polysomes synthesizing secretory protein, J. Cell Biol. 91:545-550. 
Weiss, H., and Kolb, H. J., 1979, Isolation of mitochondrial succinate:ubiquinone reductase, cytochrome $c$ reductase and cytochrome $c$ oxidase from Neurospora crassa using nonionic detergent, Eur. J. Biochem. 99:139-149.

Wickner, W., 1980, Assembly of proteins into membranes, Science 210:861-862.

Yamauchi, K., Hayashi, N., and Kikuchi, G., 1980a, Translocation of $\delta$-aminolevulinate synthase from the cytosol to the mitochondria and its regulation by hemin in the rat liver, $J$. Biol. Chem. 255:1746-1751.

Yamauchi, K., Hayashi, N., and Kikuchi, G., 1980h, Cell-free synthesis of rat liver $\delta$-aminolevulinate synthase and possible occurrence of processing of the enzyme protein in the course of its translocation from the cytosol into the mitochondrial matrix, FEBS Lett. 115:15-18.

Zimmermann, R., and Neupert, W., 1980, Transport of proteins into mitochondria. Posttranslational transfer of ADP/ATP carrier into mitochondria in vitro, Eur. J. Biochem. 109:217-229.

Zimmermann. R., Paluch, U., and Neupert, W., 1979a, Cell-free synthesis of cytochrome $c$, FEBS Lett. 108:141-146.

Zimmermann, R., Paluch, U., Sprinzl, M., and Neupert, W., 1979b, Cell-free synthesis of the mitochondrial ADP/ATP carrier protein of Neurospora crassa, Eur. J. Biochem. 99:247-252.

Zimmermann, R., Hennig, B., and Neupert, W., 1981, Different transport pathways of individual precursor proteins in mitochondria, Eur. J. Biochem. 116:455-460.

Zwizinski, C., and Wickner, W., 1980, Purification and characterization of leader (signal) peptidase from Escherichia coli, J. Biol. Chem. 255:7973-7977. 